\title{
Teachers knowledge on dental and mouth health at primary school
}

\author{
Raiandri Fajri *, Anne Agustina Suwargiani*, Netty Suryanti* \\ *Department of Dental Public Health, Faculty Of Dentistry Universitas Padjadjaran
}

\begin{abstract}
Introduction: Oral and dental health problems in elementary school-age children are problems that require treatment, both preventive and promotive. Government efforts in improving dental health knowledge of elementary school-age children are made through business Dental School Health (UKGS) by involving teachers. The teacher has the role of delivering knowledge of the causes and prevention of dental and oral health in children. Purpose of the research is to find out teacher's knowledge about oral health. Methods: The method used is descriptive, using survey techniques. Research population include 28 teachers. The study sample was all members of the population in the Public Elemen-tary School (total sampling). Results: The results showed that the teacher's knowledge about dental disease and the mouth and oral hygiene are categorized as good; knowledge about the anatomy of the oral cavity, various teeth and how to brush teeth properly are categorized as fairly good, and tooth growth knowledge and dental anatomy are cat-egorized as bad. Conclusion: The teacher does not understand oral health. Knowledge level of the teachers will influ-ence the implementation of the UKGS, namely in maintaining and improving dental and oral health of all students at school and to achieve optimal degree of the dental and oral health status of students.
\end{abstract}

Keywords: Knowledge, teachers, oral health, primary school students.

\section{INTRODUCTION}

Basic Health Research (Indonesia Basic Health Research, 2013) shows the prevalence of the national people brush who teeth every day is found to be $94.2 \%$ from 15 provinces. Correct behaviour when brushing teeth is related to gender, economic, and regional factors residence. This condition shows that people's awareness to do prevention and treatment of teeth has not been implemented. ${ }^{1}$ states that in West Java, caries in children elementary school reaches $85 \%$.
Results of interviews with students report that if their teeth hurt, then they will not attend school and difficult to eat, even some will cry because of toothache. If the tooth hurts while at school, the student is told to go home by his teacher and of course they will miss out the lesson. Factors that cause caries are due to tooth structure, oral microorganisms, the environment of the substrate (food), and the length of time the food sticks in the mouth. ${ }^{2}$ Other factors are age, gender, economic level, education level, environment, awareness and behaviour related to dental health. ${ }^{3}$. Aged 
6-12 years children begin to enter the school environment. At this age, the environment has a significant impact on the development and relationship of children with others. Therefore oral health care in early childhood is beneficial for the health of children who are in the stage of growth and development. ${ }^{4}$.

One of the government's efforts is to improve dental health knowledge in elementary school-age children, namely through the School Dental Health Effort (UKGS). UKGS Program is an effort to maintain oral health in elementary school children by emphasizing counselling and movement of tooth brushing and dental health check-up. The initiative was carried out involving teachers school. School teachers can play an important role in conveying knowledge about the causes and prevention of dental and oral health problems in elementary school-age children. At this age (6-14 years), children can easily absorb anything new. ${ }^{5}$

In order to determine the role of teachers in conveying knowledge of dental health and the mouth of the students, this study establishes SD Negeri Galih Pawarti Baleendah District Bandung Regency as a research location, which previously had received assistance in the form of material and information on dental and oral health knowledge from the Health Service and Baleendah Health Center.

The location was chosen with the consideration that SD Galih Pawarti is a school with 3rd place in the "West Java School Health Business Competition (UKS) Year 2012 ", which of course also implemented the UKGS program in it. Based on this background, this research focuses on the teachers' knowledge about dental health and mouth in the State Elementary School.

\section{METHODS}

This study uses descriptive methods with survey techniques. The study population are teachers at Galih Pawarti Elementary School, Baleendah District, Bandung Regency, who had been previously received assistance in the form of material and information about dental health knowledge and mouth in the school from the Baleendah Health Office and Puskesmas. The research sample is all of the population members, which include 28 teachers (total sampling). Tools and materials used are questionnaires, informed consent, papers, and stationery used both while in the field and after finishing from the ground.

The research procedure consisted of three stages, namely: (1) stage preparation, including activities to make research designs, research instruments, research permits, test research instruments, manufacture research information, and informed consent; (2) the implementation stage, namely the stage of field data collection; (3) the reporting stage, namely data processing, data analysis and compiling research reports. Data analysis is by pure statistics, which simplifies research data information that is simpler and easier to understand with the descriptive analysis presented in frequency distribution table form.

Measurement of knowledge is carried out by using nominal variables, i.e. only Chooses one answer that is considered most appropriate. Next, the level of expertise is categorized by using the scale of good, fairly good and poor based on the Arikunto knowledge category (2013).

\section{RESULTS}

Respondents consisted of 28 teachers, aged less than 25 years $(10.7 \%), 26-35$ years $(35.7 \%), 36$ 45 years $(21.4 \%), 45-55$ years $(25.0 \%)$ and above 55 years $(7.1 \%)$. Most respondents have previous education of degree $(78.6 \%)$ with $10.7 \%$ of them have less than 1 year of working experience, $57.1 \%$ have $2-11$ years of working experience, $3.6 \%$ have $12-21$ years of working experience and $14.3 \%$ of 22-31 years and above 32 years of working

Tabel 1. Categorized of knowledge

\begin{tabular}{cl}
\hline $\begin{array}{c}\text { Level of } \\
\text { knowledge }\end{array}$ & \multicolumn{1}{c}{ Pengukuran } \\
\hline Good & All answers are answered correctly $(>75 \%)$ \\
Fairly good & $\begin{array}{l}\text { More than half are answered correctly (60- } \\
75 \%)\end{array}$ \\
Poor & $\begin{array}{l}\text { More than half are not answered correctly } \\
(<60 \%)\end{array}$
\end{tabular}

experience. Teacher knowledge on how to keep teeth and mouth healthy (82\%) and knowledge about dental and oral disease $(78.6 \%)$ have the highest percentage. In comparison, teachers' 
knowledge about tooth growth and development (as much as 32.1\%) and tooth anatomy (as much as $42.9 \%$ ) constitute the lowest percentage. When measuring the teacher's knowledge about dental and oral health, it shows that the teacher's knowledge on how to look after teeth and the mouth remained healthy (as much as $82.1 \%$ ) and the teacher's knowledge of dental and mouth disease (78.6\%) was categorized as having good knowledge.

This shows that most respondents have good knowledge about how to look after their teeth and mouth and about dental and oral diseases. Furthermore, the teacher's knowledge about the anatomy of the oral cavity (as much as 75\%), types of teeth (as much as 75\%) and how to brush teeth correctly and adequately (as much as 67.9\%) categorized as having reasonably good knowledge.

This shows that majority of the respondents have quite good knowledge about the anatomy of the oral cavity, various kinds of teeth, and how to brush teeth properly. Teachers' knowledge about tooth anatomy (as much 32.1\%) and tooth growth (as many as $57.1 \%$ ) are categorized as having poor knowledge. This shows that the majority of respondents have poor knowledge about tooth anatomy and tooth growth.

Teacher's knowledge about lip function, tongue function, saliva function and healthy gum state shows that more than $75 \%$ of respondents answered correctly. While the knowledge about the definition of teeth who answered correctly is as many as $75 \%$ of the respondents. While for knowledge of tooth function is as much as $64 \%$ of respondents answered wrongly. If measurements are made against teacher knowledge about the

Table 2. Knowledge of Dental and Oral Health

\begin{tabular}{|c|c|c|}
\hline $\begin{array}{l}\text { Category of } \\
\text { knowledge }\end{array}$ & $\begin{array}{l}\text { Knowledge of oral } \\
\text { cavity anatomy }\end{array}$ & Percentage \\
\hline Good & $\begin{array}{l}\text { Healthy gum state } \\
\text { Saliva function } \\
\text { Tongue function } \\
\text { Lips function }\end{array}$ & $\begin{array}{l}82,1 \% \\
78,6 \%\end{array}$ \\
\hline Fairy Good & Teeth definition & $\begin{array}{l}75,0 \% \\
75,0 \% \\
67,9 \%\end{array}$ \\
\hline Poor & Teeth function & $\begin{array}{l}42,9 \% \\
32,1 \%\end{array}$ \\
\hline
\end{tabular}

anatomy of the oral cavity, they are categorized as good, knowledge about dental definitions are categorized fairly good, and knowledge of dental functions is categorized as poor.

Teachers' knowledge about dental anatomy showed that $85.7 \%$ of respondents answered correctly regarding the statement of the pulp chamber, $75 \%$ answered correctly about the anatomy of dentin, as many as $67.9 \%$ answered correctly about the anatomy of the pulp chamber. Meanwhile, for knowledge about dentin, as many as $53.6 \%$ of respondents answered wrongly, as well as for knowledge about enamel who answered wrong is $60.7 \%$.

When categorizing teachers' knowledge about tooth anatomy, the results are categorized as good for knowledge of the pulp chamber. In contrast, for knowledge about the anatomical description of dentin and pulp chamber is categorized as fairly good and for knowledge regarding enamel and dentin are categorized as poor.

The teacher's knowledge about the types of teeth includes incisors, canines, molars, along with their functions and an explanation of incisors and canines, showing more than $75 \%$ of respondents answered correctly. While for knowledge about the dental explanation of canine, $60.7 \%$ answered incorrectly, as well as knowledge about the explanation of molars, $57.1 \%$ answered incorrectly. When measuring the teacher's knowledge about kinds of teeth, the results are categorized as good for knowledge about the description of canines, molars, incisors, the function of incisors, function of molars, function of canine, and explanation of incisors. While for knowledge about canine teeth,

Table 3. Knowledge of Oral Anatomy

\begin{tabular}{ccc}
\hline $\begin{array}{c}\text { Category of } \\
\text { knowledge }\end{array}$ & $\begin{array}{c}\text { Knowledge of oral cavity } \\
\text { anatomy }\end{array}$ & Percentage \\
\hline \multirow{2}{*}{ Good } & Healthy gum state & $100,0 \%$ \\
& Saliva function & $96,4 \%$ \\
& Tongue function & $92,9 \%$ \\
& Lips function & $92,9 \%$
\end{tabular}

Fairy Good $\quad$ Teeth definition $\quad 75,0 \%$ 
Table 4. Knowledge of Dental Anatomy

\begin{tabular}{|c|c|c|}
\hline $\begin{array}{l}\text { Category of } \\
\text { knowledge }\end{array}$ & $\begin{array}{c}\text { Knowledge of oral cavity } \\
\text { anatomy }\end{array}$ & Percentage \\
\hline Good & Pulp chamber & $\begin{array}{c}100,0 \% \\
96,4 \% \\
92,9 \% \\
92,9 \%\end{array}$ \\
\hline Fairy Good & $\begin{array}{c}\text { Dentin } \\
\text { Pulp anatomy } \\
\text { Dentin }\end{array}$ & $75,0 \%$ \\
\hline Poor & Enamel & $35,7 \%$ \\
\hline $\begin{array}{l}\text { Category of } \\
\text { knowledge }\end{array}$ & $\begin{array}{c}\text { Knowledge of oral cavity } \\
\text { anatomy }\end{array}$ & Percentage \\
\hline Good & $\begin{array}{l}\text { Explanation of incisors } \\
\text { Description of molars } \\
\text { Description of canines } \\
\text { Description of incisors } \\
\text { Function of molars } \\
\text { Function of incisors } \\
\text { Function of canines }\end{array}$ & $\begin{array}{l}100,0 \% \\
96,4 \% \\
92,9 \% \\
92,9 \% \\
89,3 \% \\
82,1 \% \\
82,1 \%\end{array}$ \\
\hline Fairy Good & $\begin{array}{l}\text { Explanation of molars } \\
\text { Explanation of canines }\end{array}$ & $\begin{array}{l}42,9 \% \\
39,3 \%\end{array}$ \\
\hline
\end{tabular}

explanation and molars are categorised as poor.

The teacher's knowledge about the number of adult teeth and the components of adult teeth shows more than $75 \%$ of respondents answered correctly. While the teacher's knowledge about the first deciduous teeth starts to grow showed as much as $64.3 \%$ answered incorrectly, likewise knowledge of the number of baby teeth, the components of milk teeth, and molars growing in the period of the permanent dentition show less than $60 \%$ of respondents answered wrongly.

When measurements are taken of teacher knowledge about tooth growth, the results are categorized as good for knowledge of the number of adult teeth and components of adult teeth. In contrast, the category of knowledge is poor for the first tooth growing period of deciduous teeth,

Table 6. Knowledge of Dental Growth

\begin{tabular}{ccc}
\hline $\begin{array}{c}\text { Category of } \\
\text { knowledge }\end{array}$ & $\begin{array}{c}\text { Knowledge of oral } \\
\text { cavity anatomy }\end{array}$ & Percentage \\
\hline \multirow{3}{*}{ Good } & $\begin{array}{c}\text { Total permanent teeth } \\
\text { Component of permanent } \\
\text { teeth }\end{array}$ & $\begin{array}{c}100,0 \% \\
85,7 \%\end{array}$ \\
\hline \multirow{3}{*}{ Fairy Good } & The growing period of & $57,1 \%$ \\
& molarsDeciduous teeth & $53,6 \%$ \\
& component Total decid- & $42,9 \%$ \\
& uous teeth First growing & $35,7 \%$ \\
& deciduous tooth & \\
\hline
\end{tabular}

number of baby teeth, baby teeth components, and molars growing in the adult period. The teacher's knowledge about the order of how to brush teeth, things that must be considered in brushing teeth, and the characteristics of a proper tooth brushing show more than $75 \%$ of respondents answered correctly.

While as many as $75 \%$ of respondents answered correctly about good toothpaste. When measuring teachers' knowledge about how to brush teeth correctly, the results are categorized as good for knowledge about the order of how to brush teeth, things to consider in brushing

Table 7. Knowledge of Dental Growth

\begin{tabular}{ccc}
\hline $\begin{array}{c}\text { Category of } \\
\text { knowledge }\end{array}$ & $\begin{array}{c}\text { Knowledge of oral } \\
\text { cavity anatomy }\end{array}$ & Percentage \\
\hline \multirow{4}{*}{ Good } & $\begin{array}{l}\text { Things to be considered } \\
\text { during tooth brushing } \\
\text { characteristics of a } \\
\text { proper tooth brushing } \\
\text { order of tooth brushing }\end{array}$ & $\begin{array}{c}100,0 \% \\
92,9 \%\end{array}$ \\
\hline Fairy Good & Good toothpaste & $75,0 \%$ \\
\hline
\end{tabular}

your teeth, and the characteristics of a good. A reasonably good category for knowledge of good toothpaste. Knowledge about dental and oral disease shows that more than $75 \%$ of respondents answer correctly about dental and oral diseases. If measurements are made against teacher knowledge about dental and oral diseases, the results are categorized as suitable for all understanding of dental and oral diseases.

The teacher's knowledge about brushing time, nutritious foods, and regular check-ups to dentists show that more than $75 \%$ of respondents answered correctly. While knowledge of the frequency of brushing teeth as much as 75\% answered correctly as well as learning about good habits as much as $67.9 \%$ answer correctly. When

Table 8. Knowledge of Dental and Oral Diseases

\begin{tabular}{ccc}
\hline $\begin{array}{c}\text { Category of } \\
\text { knowledge }\end{array}$ & $\begin{array}{c}\text { Knowledge of oral } \\
\text { cavity anatomy }\end{array}$ & Percentage \\
\hline & & \\
Good & Causes of gingivitis & $100,0 \%$ \\
& Causes of calculus & $100,0 \%$ \\
& Causes of cavity & $100,0 \%$ \\
& Caries progression & $78,6 \%$ \\
\hline
\end{tabular}


Table 9. Knowledge of "How to Keep Your Teeth and Mouth Healthy"

\begin{tabular}{ccc}
\hline $\begin{array}{c}\text { Category of } \\
\text { knowledge }\end{array}$ & $\begin{array}{c}\text { Knowledge of oral cavity } \\
\text { anatomy }\end{array}$ & Percentage \\
\hline \multirow{3}{*}{ Good } & Time to brush teeth & $100,0 \%$ \\
& Nutritious food & $100,0 \%$ \\
& Regular dental check-up & $96,4 \%$ \\
Fairy Good & Tooth brushing frequency & $75,0 \%$ \\
& $67,9 \%$ \\
\hline
\end{tabular}

measuring teacher knowledge about how to look after teeth and the mouth to remain healthy, the results are categorized as good for learning about the time to brush teeth, nutritious foods, and regular dental check-ups. At the same time, the categories are fairly good for knowledge of brushing frequency and good habits.

\section{DISCUSSION}

The results of research on all teachers in the Elementary School about dental health knowledge shows that knowledge which is categorized as good consists of knowledge about how to keep your teeth and mouth healthy and knowledge about oral disease. Good understanding, can happen because it is influenced by various factors. Knowledge can be influenced by various factors, including media exposure and information obtained from daily life such as tv media, radio and newspapers.

The media and information provide knowledge, so that someone can remember, understand and apply this in everyday life. This is in line with the concept of knowledge that knowledge is obtained through the five senses, and the results can be the basis for someone to be applied in everyday life.

Benefit from gaining knowledge about how to keep your oral cavity healthy, includes knowledge about the frequency of brushing teeth, nutritious food and dental examinations regularly. In obtaining knowledge of frequency of brushing teeth, one can avoid tooth problems. This is in line with the opinion, the acquisition of this knowledge will know how to maintain healthy teeth and reduce the number of bacteria in the mouth.

A regular dental check up can detect dental abnormalities. The benefits of gaining knowledge about dental and oral diseases include knowledge about dental caries, the process of dental caries, gingivitis and calculus. ${ }^{7}$ With the knowledge of caries, one can know about the causes of dental caries. With such knowledge, one will also know about the process of dental caries formation, ways to avoid it as well as about the damages to the teeth.

With the knowledge of gingivitis, the acquisition of this knowledge will show clinical signs or features that occur when gingivitis and know the causes of gingivitis and its supporting factors. For the understanding of calculus, with the acquisition of this knowledge, one will know about the causes of tartar and the process of formation of calculus as well the subsequent treatment.

Measurement results about oral health knowledge that shows knowledge which is not right, consisting of knowledge of tooth anatomy and tooth growth. Lack of teacher knowledge about tooth anatomy and tooth growth among them is due to the lack of providing education about dental anatomy from health services or health facilities, nor does it provide material on an ongoing basis.

The causes of this not good knowledge about dental anatomy and tooth growth are related to lack of knowledge. The benefits of gaining knowledge about dental anatomy include knowledge about dental elements, namely to include knowledge about enamel, dentin and pulp chamber. On the knowledge of enamel, the acquisition of that knowledge will be known about the hardest tissue in the body. The knowledge of dentin will be known that in dentin, there are nerve endings and the knowledge of the pulp chamber, the pulp chamber is to store blood vessels in the teeth.

The benefits of gaining knowledge about tooth growth include knowledge about the growth of teeth of children and adults and the number of teeth of children and adults. On knowledge about the growth of teeth of children and adults, the acquisition of this knowledge, will be known about the date of the child's teeth, namely when the child's teeth will be replaced with adult teeth, as well as first teeth that grow in the period of the child's teeth and adulthood.

Next to the knowledge about the number of teeth of children and adults, the acquisition of this knowledge, will be known the dental components 
in the period of the child and adult teeth. The results of the discussion above show that teachers do not understand about oral health. Based on these results, the level of teacher knowledge about oral health will affect the implementation of UKGS, namely in maintaining and improve dental and oral health of all students at school and to achieve optimal degree of dental and oral health of students Lack of understanding of oral health is influenced by the role of teachers in the organization of education and oral health services in schools. the role of the teacher in the learning process of students, namely as a planner, executor, and appraiser. ${ }^{8-9}$

The role of the teacher in giving education about oral health includes activities such as leading the mass tooth brushing technique with fluoride toothpaste, gargling mouth rinse with flour solution, netting grade 1 students in elementary school, provide health education, and refer students to the Puskesmas.

Related to research, hence the role of the teacher in the UKGS in SDN is limited only to the role in leading mass tooth brushing technique with fluoride toothpaste, role in providing health education and role in referring students to Public health centre. Teachers' knowledge about oral health is essential to optimize UKGS activities. The Health Office needs to provide training for UKGS supervisor teachers and small doctors, to carry out prevention on oral disease by carrying out daily toothbrush activities with fluoride toothpaste, train teachers in conducting emergency medicine for relieving pain, do dental and oral health screening at the beginning of the year, provide referrals for those in need, and provide education and counselling about dental health carried out by UKGS supervisors / physical education teachers / small doctors, and to be carried out at least once a month. ${ }^{9}$

Teachers have an important role in achieving success in student learning, because the teacher acts as a liaison guide and coordinator for the health of the school through the implementation of the UKGS program. UKGS is one of the programs that can bridge the importance of dental hygiene in schools. Through UKGS, it is expected to have a better achievement of the optimal degree of dental and oral health of students. ${ }^{10}$ Through counselling and optimizing UKGS activities, it is expected to provide sustainable benefits for change in healthy behaviour both for individuals and society.

\section{CONCLUSION}

The conclusion of the teacher's knowledge about dental and oral health in the Public Elementary School is categorized as good, includes knowledge about dental and oral diseases as well as ways to maintain teeth and mouth.

Fairly good category for the category which consists of the knowledge of the oral cavity anatomy, types of teeth and proper tooth brushing methods and finally the category of poor knowledge, including knowledge of tooth growth and tooth anatomy.

\section{REFERENCES}

1. Schuurs AHB. Patologi Gigi Gigi : Kelainan jaringan keras gigi. a Yogyakarta : Gajah Mada University Press. 1992

2. Suwelo IS. Peranan pelayanan kesehatan gigi anak dalam menunjang kualitas sumber daya manusia Indonesia di masa mendatang. Jakata : Universitas Indonesia. 1997.

3. Dewanti. Hubungan Tingkat Pengetahuan tentang Kesehatan Gigi dengan Perilaku Perawatan Gigi pada Anak Usia Sekolah di SDN Pondok Cina 4 Depok. Depok : Universitas Indonesia. 2012.

4. Astoeti, Tri Erri. Pendidikan Kesehatan Gigi di Sekolah. Jakarta : PT. Rajagrafindo Persada. 2006.

5. Putri, Indah N. Efek Penyuluhan Kesehatan Gigi Dan Mulut Dengan Demonstrasi Cara Menyikat Gigi Terhadap Penurunan Indeks Plak Pada Murid Kelas Vi Sekolah Dasar (Penenelitian Dilakukan Di Desa Padang Loang Kecamatan Patampanua Kabupaten Pinrang). Makasar : Universitas Hasanudin. 2012

6. Ghofur, Abdul. Buku Pintar Kesehatan Gigi dan Mulut. Yogyakarta : MITRA BUKU. 2012.

7. Syamsyudin, Abin. Psikologi Pendidikan. Bandung : PT. Remaja Rosda Karya. 2003.

8. Hutabarat, Natalina. Peran Petugas Kesehatan, Guru, dan Orang tua dalam Pemeliharaan UKGS dengan Tindakan Pemelihraan Kesehatan Gigi dan Mulut Murid Sekolah Dasar di Kota Medan. 
Medan : Universitas Smatra Utara. 2009.

9. KEMENKES RI. Rencana Program Pelayanan Kesehatan Gigi dan Mulut. Kemenkes RI: Jakarta. 2012
10. Basir, Ariyanicl. Gambaran Pengetahuan Dan Sikap Guru Penjaskes Berbasis Ukgs Dan Non Ukgs Di SDN Kota Makassar. Unhas: Jakarta. 2011 